\title{
KEMAMPUAN Trichoderma sp. DAN FILTRATNYA DALAM MENEKAN PERTUMBUHAN Sclerotium rolfsii SECARA IN VITRO
}

\author{
Indah Puspita Dewi, Tri Maryono, Titik Nur Aeny \& Suskandini Ratih \\ Jurusan Agroteknologi, Fakultas Pertanian Universitas Lampung \\ Jl. Prof. Dr. Soemantri Brodjonegoro no. 1 Bandar Lampung 35145 \\ Email : indah09may@yahoo.com
}

\begin{abstract}
ABSTRAK
Salah satu penyebab rendahnya produksi kedelai nasional adalah adanya serangan penyebab penyakit rebah kecambah. Pengendalian yang dapat dilakukan adalah dengan menggunakan agen antagonis. Penelitian ini bertujuan mengetahui kemampuan Trichoderma sp. dan filtratnya dalam menekan pertumbuhan Sclerotium rolfsii secara in vitro. Pengujian terdiri atas uji antagonisme dengan metode kultur ganda dan uji filtrat Trichoderma sp. terhadap pertumbuhan $S$. rolfsii. Percobaan disusun dalam Rancangan Acak Lengkap (RAL) dengan lima ulangan. Data yang diperoleh dianalisis dengan sidik ragam dan dilanjutkan dengan uji BNT pada taraf nyata 5\%. Hasil penelitian menunjukkan bahwa Trichoderma sp. dan filtratnya mampu menekan pertumbuhan $S$. rolfsii secara in vitro. Isolat Trichoderma sp. yang kemampuan penghambatannya paling tinggi adalah isolat Trichoderma harzianum.
\end{abstract}

Kata kunci : Rebah kecambah, Sclerotium rolfsii, Trichoderma sp.

\section{PENDAHULUAN}

Kedelai merupakan komoditas tanaman pangan yang penting di Indonesia. Produksi kedelai di Indonesia mencapai angka 0,8 juta ton per tahun, sedangkan kebutuhan kedelai di Indonesia mencapai 2,5 juta ton per tahunnya (Kementan, 2013). Untuk itu perlu adanya upaya dalam meningkatkan produksi kedelai.

Upaya meningkatkan produksi kedelai masih mengalami banyak kendala, di antaranya: lahan yang kurang tersedia bagi petani kedelai dan serangan hama dan penyebab penyakit. Serangan hama dan penyebab penyakit dapat mengakibatkan penurunan produksi tanaman kedelai. Salah satu penyakit yang sering ditemukan dalam budidaya tanaman kedelai adalah penyakit rebah kecambah (damping - off) yang disebabkan oleh Sclerotium rolfsii.

Patogen $S$. rolfsii relatif sulit dikendalikan karena mampu bertahan selama bertahun-tahun di dalam tanah dalam bentuk sklerotia dan mempunyai kisaran inang yang luas (Semangun, 1993). Pengendalian menggunakan fungisida belum memberikan hasil yang baik, justru memberikan dampak negatif. Oleh karena itu diperlukan cara pengendalian lain yang lebih ramah lingkungan (Soesanto, 2008) misalnya pengendalian hayati dengan agen antagonis.
Salah satu jamur antagonis yang sering digunakan adalah Trichoderma sp. Trichoderma sp. merupakan salah satu jamur antagonis yang banyak digunakan untuk mengendalikan jamur patogen tumbuhan. Mekanisme antagonis jamur Trichoderma sp. adalah parasitisme, lisis, antibiosis, dan kompetisi ruang (Soesanto, 2008). Selain dapat digunakan langsung untuk mengendalikan patogen, filtrat Trichoderma sp. juga dilaporkan dapat mengendalikan patogen tumbuhan (Radder, 2005).

\section{BAHAN DAN METODE}

Sebanyak 4 isolat Trichoderma sp. yaitu $T$. koningii, T. koningii, T. harzianum, dan Trichoderma sp. yang digunakan dalam percobaan ini didapatkan dari koleksi Laboratorium Penyakit Tanaman, Bidang Proteksi Tanaman, Jurusan Agroteknologi, Fakultas Pertanian Universitas Lampung. Keempat isolat tersebut diperoleh dari hasil isolasi tanah rizosfer tanaman cabai.

Keempat isolat Trichoderma sp. yang digunakan berasal dari pengelompokkan 11 isolat yang dibedakan dari warna dan pola koloni jamur. Biakan Trichoderma sp. terlebih dahulu diremajakan pada media PDA sebelum digunakan dalam pengujian. Peremajaan dilakukan dengan cara meletakkan potongan berbentuk cakram Trichoderma berukuran $4 \mathrm{~mm}$ ke dalam me- 
dia PDA baru dan kemudian diinkubasi selama 7 hari. Setelah tumbuh, Trichoderma sp. diperbanyak pada media PDA baru dan selanjutnya digunakan untuk pengujian.

Untuk mendapatkan filtrat Trichoderma, jamur ini terlebih dahulu dibiakkan pada media cair potato dextrose broth (PDB). Komposisi media cair yang digunakan sama dengan komposisi media PDA, tetapi tanpa menggunakan agar. Sebanyak 5 potongan cakram Trichoderma sp. dimasukkan dalam $500 \mathrm{ml}$ media cair yang sudah disiapkan dalam tabung Erlenmeyer, kemudian diinkubasi selama 7 hari pada suhu ruang dengan pencahayaan matahari. Setelah 7 hari, media cair tesebut disaring untuk memisahkan struktur jamur dengan cairannya. Filtrat tersebut selanjutnya digunakan dalam pengujian.

Pengujian dengan metode kultur ganda dilakukan untuk mengetahui kemampuan Trichoderma sp. dalam kemampuan parasitisme, persaingan ruang dan nutrisi, serta antibiosis dan lisis. Biakan Trichoderma sp. yang telah diinkubasi selama 4 hari kemudian dipindahkan ke dalam media PDA yang baru dengan menggunakan cork borer berdiameter $4 \mathrm{~mm}$. Isolat patogen yang telah diinkubasi selama 4 hari kemudian dipindahkan ke media PDA yang sama dengan Trichoderma sp. Potongan cakram Trichoderma sp. diletakkan $3 \mathrm{~cm}$ dari tepi cawan, sedangkan potongan cakram isolat patogen diletakkan $3 \mathrm{~cm}$ dari tepi cawan pada bagian sisi depan cuplikan Trichoderma sp, kemudian diinkubasi (Gambar 1). Peubah yang diamati adalah jari-jari pertumbuhan koloni patogen. Pengukuran jari-jari pertumbuhan koloni

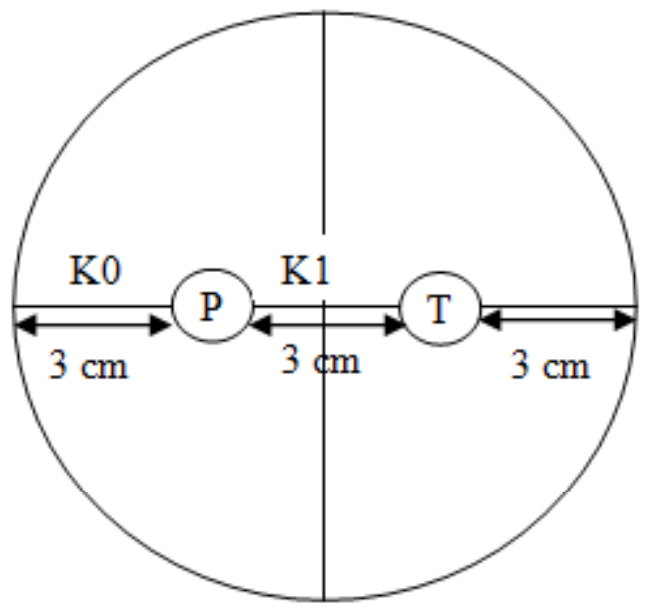

Gambar 1. Tata letak jamur Trichoderma sp. dan $S$. rolfsii pada uji antagonisme dalam cawan petri. $(\mathrm{P}=$ biakan $S$. rolfsii, $\mathrm{T}=$ biakan Trichoderma sp.). patogen dilakukan dengan cara mengukur jari-jari pertumbuhan koloni yang tumbuh ke arah biakan Trichoderma sp. sebagai data perlakuan dan ke arah tepi cawan sebagai data kontrol. Pengukuran jari-jari dilakukan setiap hari sampai pertumbuhan koloni pada kontrol mencapai tepi cawan. Untuk mengetahui ada tidaknya lisis dan antibiosis dilakukan pengamatan pada titik pertemuan patogen dan Trichoderma sp. yang ditunjukkan adanya batas yang jelas antara koloni patogen dan Trichoderma sp. atau adanya warna kuning atau coklat yang dilihat dari bagian bawah cawan.

Pada pengujian ini, media yang digunakan adalah campuran filtrat Trichoderma dan media PDA dengan perbandingan 1:1. Sebanyak $25 \mathrm{ml}$ filtrat Trichoderma dicampur dengan $25 \mathrm{ml}$ media PDA yang belum jadi, lalu diotoklaf pada suhu $121{ }^{\circ} \mathrm{C}$ selama 10 menit. Untuk perlakuan kontrol, media yang digunakan hanya media PDA tanpa filtrat Trichoderma. Setelah selesai diotoklaf dan cukup dingin, media uji tersebut dituang dalam cawan petri dan dibiarkan membeku. Setelah beku, sebanyak 1 sklerotia $S$. rolfsii diletakkan tepat ditengah cawan lalu diinkubasi pada suhu ruang dengan pencahayaan matahari.

Peubah yang diamati adalah pertumbuhan koloni jamur S. rolfsii. Pengamatan dilakukan setiap hari dengan mengukur pertumbuhan koloni S.rolfsii. Pengukuran dihentikan apabila pada perlakuan kontrol pertumbuhan koloni S.rolfsii telah mencapai tepi cawan petri. Perlakuan pada percobaan ini adalah filtrat dari 4 isolat Trichoderma sp. ditambah dengan 1 perlakuan kontrol. Masing-masing perlakuan diulang sebanyak 5 kali. Setelah data jari-jari dan diameter didapatkan kemudian dihitung persentase penghambatan Trichoderma sp. terhadap pertumbuhan koloni patogen dengan rumus (Nduagu et al., 2008) :

$$
P=\frac{K_{0}-K_{1}}{K_{0}} \times 100 \%
$$

$\mathrm{P}$ adalah persentase penghambatan, $\mathrm{K}_{0}=$ jari-jari koloni patogen ke arah tepi cawan petri (kontrol), dan $\mathrm{K}_{1}=$ jari-jari koloni patogen ke arah biakan Trichoderma sp.

\section{HASIL DAN PEMBAHASAN}

Hasil pengujian antagonisme dengan metode kultur ganda menunjukkan bahwa semua isolat Trichoderma yang diuji mampu menghambat pertumbuhan $S$. rolfsii (Tabel 1). Keempat isolat Trichoderma sp. pada $1 \mathrm{hsi}$ dan 2 hsi tidak berbeda nyata, namun pada 3 hsi, isolat T. koningii 1 berbeda nyata dibandingkan dengan ketiga 
Tabel 1. Persentase penghambatan Trichoderma sp. terhadap pertumbuhan koloni S. Rolfsii.

\begin{tabular}{cccc}
\hline \multirow{2}{*}{ Isolat } & \multicolumn{3}{c}{ Persentase penghambatan } \\
\cline { 2 - 4 } & $1 \mathrm{hsi}$ & $2 \mathrm{hsi}$ & $3 \mathrm{hsi}$ \\
\hline T. koningii 1 & $7,73 \mathrm{a}$ & $47,34 \mathrm{a}$ & $54,67 \mathrm{~b}$ \\
T. koningii 2 & $10,37 \mathrm{a}$ & $47,36 \mathrm{a}$ & $59,33 \mathrm{a}$ \\
T. harzianum & $11,84 \mathrm{a}$ & $49,32 \mathrm{a}$ & $63,33 \mathrm{a}$ \\
Trichoderma sp. & $7,82 \mathrm{a}$ & $46,77 \mathrm{a}$ & $59,33 \mathrm{a}$ \\
\hline
\end{tabular}

Keterangan: Angka-angka yang diikuti huruf yang sama menunjukkan tidak berbeda nyata berdasarkan uji BNT $5 \%$. hsi = hari setelah inokulasi.

isolat Trichoderma sp. yang lain (T. koningii 2, T. harzianum dan Trichoderma sp.). Lalu, setelah dilakukan uji lanjut dengan BNT, terlihat adanya perbedaan persentase penghambatan isolat $T$. koningii 1 dibandingkan dengan isolat lainnya. Isolat Trichoderma yang tingkat penghambatannya paling rendah adalah isolat $T$. koningii 1 pada 3 hsi.

Hasil pengujian filtrat Trichoderma sp. terhadap pertumbuhan $S$. rolfsii menunjukkan bahwa semua filtrat isolat Trichoderma yang diuji mampu menghambat pertumbuhan $S$. rolfsii. Filtrat isolat Trichoderma dengan persentase penghambatan paling rendah adalah filtrat dari isolat $T$. koningii 1 (Tabel 2). Bila dilihat dari laju pertambahan pertumbuhan $S$. rolfsii setiap hari, terlihat bahwa filtrat dari isolat $T$. koningii 1 memiliki laju pertambahan pertumbuhan tertinggi. Hasil analisis statistik laju pertambahan pertumbuhan $S$. rolfsii dan diameter koloni $S$. rolfsii pada 4 hsi menunjukkan bahwa kemampuan Trichoderma isolat $T$. harzinum berbeda nyata dengan isolat $T$. koningii $1, T$. koningii 2 dan Trichoderma sp. dalam kemampuan menghambat pertumbuhan koloni $S$. rolfsii.

Hasil penelitian menunjukkan bahwa penggunaan Trichoderma sp. atau filtratnya mampu menekan pertumbuhan $S$. rolfsii. Hal ini terlihat dari terhambatnya pertumbuhan S. rofsii saat terpapar dengan Trichoderma sp. atau filtratnya. Pada pengujian dengan metode kultur ganda, mekanisme penghambatan yang terjadi adalah kompetisi ruang dan antibiosis. Kompetisi ruang yaitu pertumbuhan Trichoderma sp. lebih cepat dibandingkan pertumbuhan $S$. rolfsii yang kemudian menyebabkan Trichoderma sp. dapat memenuhi ruang lebih cepat di dalam cawan petri, sehingga pertumbuhan $S$. rolfsii menjadi berkurang. Selain itu, mekanisme antibiosis juga terjadi pada pengujian ini yang dapat dilihat dengan adanya batas berwarna kuning kecoklatan di antara Trichoderma sp. dan S. rolfsii. Pertumbuhan
S. rolfsii terhenti pada batas berwarna kecoklatan tersebut. Hal ini diduga karena adanya suatu senyawa yang menghalangi $S$. rolfsii tumbuh ke arah Trichoderma sp.

Pada pengujian menggunakan filtrat Trichoderma sp., diduga kemampuan menghambat disebabkan oleh kandungan enzim dan toksin. Enzim dan toksin yang dihasilkan Trichoderma mampu menghambat patogen dengan merusak dinding sel patogen (Pietro et al., 1993). Menurut El-Katatny et al. (2000), filtrat Trichoderma sp. mengandung enzim kitinase dan $\beta-1,3-$ glukanase, sedangkan Mukherjee et al. (2012) melaporkan bahwa filtrat Trichoderma sp. mengandung toksin harzianic acid, tricholin, peptaibols, gliotoxin, viridian, T22azaphilone, 1 hydroxy-3-methyl-anthraquinone, 1,8-dihydroxy-3-methyl-anthraquinone, T39butenolide, harzianolide, dan harzianopyridone. Gveroska dan Ziberoski (2012) melaporkan bahwa filtrat Trichoderma sp. efektif menghambat Alternaria alternata dan mengakibatkan abnormalitas morfologi patogen. Sementara itu, menurut Radder (2005) filtrat dari Trichoderma sp. mampu menghambat pertumbuhan miselia dan pembentukan sklerotia dari $S$. rolfsii penyebab penyakit layu pada kacang tanah.

Pada penelitian ini, meskipun filtrat Trichoderma diotoklaf, namun masih menunjukkan kemampuan menghambat pertumbuhan koloni $S$. rolfsii. Hal ini mengindikasikan bahwa metabolit sekunder (enzim dan toksin) Trichoderma yang terkandung dalam filtrat tidak mengalami kerusakan setelah dilakukan pemanasan pada otoklaf dengan suhu $121^{\circ} \mathrm{C}$ dan tekanan $1 \mathrm{~atm}$ selama 10 menit. Xiao-Yan (2006) melaporkan bahwa enzim trikokonin tidak mengalami kerusakan setelah dilakukan pemanasan pada suhu $121^{\circ} \mathrm{C}$ selama 15 menit. Sedangkan menurut Radder (2005), filtrat Trichoderma masih efektif menghambat pertumbuhan S. rolfsii meskipun telah disterilisasi dengan cara diotoklaf. 
Tabel 2. Rata-rata pertumbuhan koloni $S$. rolfsii yang ditumbuhkan pada media yang mengandung fitrat Trichoderma sp.

\begin{tabular}{lcc}
\hline \multicolumn{1}{c}{ Perlakuan Isolat } & $\begin{array}{c}\text { Laju pertambahan pertumbuhan } \\
\text { koloni S.rolfsii per hari }(\mathrm{cm})\end{array}$ & $\begin{array}{c}\text { Diameter koloni } S \text {. rolfsii }(\mathrm{cm}) \\
\text { pada } 4 \mathrm{hsi}\end{array}$ \\
\hline Kontrol (tanpa Trichoderma) & $2,25 \mathrm{a}$ & $9,0 \mathrm{a}$ \\
T. koningii 1 & $1,78 \mathrm{~b}$ & $7,1 \mathrm{~b}$ \\
T. koningii 2 & $1,75 \mathrm{~b}$ & $7,0 \mathrm{~b}$ \\
T. harzianum & $1,03 \mathrm{c}$ & $4,1 \mathrm{c}$ \\
Trichoderma sp. & $1,75 \mathrm{~b}$ & $7,0 \mathrm{~b}$ \\
\hline
\end{tabular}

Keterangan : Angka-angka yang diikuti huruf yang sama menunjukkan tidak berbeda nyata berdasarkan uji BNT $5 \%$. hsi $=$ hari setelah inokulasi.

\section{KESIMPULAN}

Berdasarkan hasil penelitian dapat disimpulkan bahwa Trichoderma sp.dan filtratnya mampu menghambat pertumbuhan Sclerotium rofsii. Isolat Trichoderma sp. yang memiliki memiliki kemampuan tertinggi dalam menghambat $S$. rofsii adalah isolat Trichoderma harzianum

\section{DAFTAR PUSTAKA}

Di Pietro, A., M. Lorito, C. K. Hayes, R. M. Broadway, and G. E. Harman. 1993. Endochitinase from Gliocladium virens: isolation, characterization, and synergistic antifungal activity in combination with gliotoxin. Phytopathology. 83: 308-313.

El-katatny, M.H., Somitsch, W., Robra, K.H., ElKatatny., and Gubitz, G.M. 2000. Production of chitinase and $\beta$-1,3-glucanase by T. harzianum, Food technol. Biotechnol. 38(3): 173-180.

Gveroska, B., and Ziberoski, J. 2012. Trichoderma harzianum as a biocontrol agent against Alternaria alternata on tobacco. J. Appl. Technol. \& Innov. 7(2): 67-76.

Kementan. 2013. Produksi Tanaman Pangan. http:// aplikasi.pertanian.go.id/bdsp/ hasil kom.asp. Diakses pada tanggal : 5 Maret 2014.
Mukherjee, P.K., Horwitz, B.A., dan Kenerly, C.M. 2012. Secondary metabolism in Trichoderma - a genomic perspective. Microbiol. 158:35-45.

Nduagu C., Ekefan E.J., and Nwankiti A. O. 2008. Effect of Some Crude Plant Extracts on Growth of Colletotrichum capsici (Synd) \&Bisby, Causal Agent of Pepper Antracnose. J. of Applied Biosci. 6(2): 184-190.

Radder, Siddanagoudar R., 2005. Effect of bioagents and their metabolites on sclerotium rolfsii Sacc of groundnut. Thesis Master of Science. University of Agricultural Sciences. Dharward.

Semangun, H. 1993. Penyakit Tanaman Pangan di Indonesia. Universitas Gadjah Mada. Yogyakarta.

Soesanto, L. 2008. Pengantar Pengendalian Penyakit Tanaman. Rajawali Pers. PT. Raja Grafindo Persada. Jakarta.

Xiao-Yan. S, Shen Qing-Tao, Xie Shu-Tao, Chen XiuLan, Sun Cai-Yun \& Zhang Yu-Zhong.2006. Broad-spectrum antimicrobial activityand high stability of Trichokonins fromTrichoderma koningii SMF2 against plant pathogens. State Key Laboratory of Microbial Technology, Shandong University. China. 